\title{
Mediating Knowledge through Peer-to-Peer Interaction in a Multicultural Online Learning Environment: A Case Study of International Students in the US
}

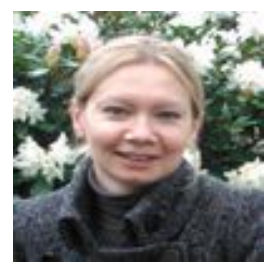

Gulnara Sadykova

Kazan (Volga Region) Federal University, Russian Federation

\section{Abstract}

The continuous growth of online learning and its movement towards cross-border and cross-culture education has recently taken a new turn with the epic hype that currently surrounds the development of massive open online courses (MOOCs) (Beattie-Moss, 2013). This development brings to focus the experiences of international students who take online courses designed and offered within the paradigm of Western pedagogy. Employing a sociocultural theoretical framework (Vygotsky, 1978; Scollon \& Scollon, 2001), this paper examines the mediating roles that peers may play in the context of multicultural online learning environments. This two-stage, mixed methods study explored the experiences of 12 international graduate students who took fully online courses in a large research university in the northeastern region of the United States. The data included a survey, online interviews, as well as a case study that took a close look at the experiences of a female student from China. Findings of the study demonstrated that international students that come from diverse native academic backgrounds and cultures may necessitate a close relationship with peers they meet in the US courses. Peers become invaluable mediators of knowledge for international students who seek peer assistance to compensate for the lack of culture-specific knowledge and skills and to satisfy their interest in the host culture. The study suggests that course developers and facilitators should be proactive when assigning group projects and activities so as to enable close peer-to-peer interaction and opportunities for building personal relationships with other class members. 
Keywords: Online learning; international students; peer-to-peer learning; culture; sociocultural framework

\section{Introduction}

While most universities and colleges see their native citizens as their primary target audience, growing world population mobility and interest in higher education have increased the number of students who wish to obtain a tertiary degree from a foreign institution. It is predicted that by the year 2025, there will be about 8 million international students as compared to 2 million in 2004 (Albach, 2004). Currently most of those students - over 764,000 - are heading to the United States making higher education one of the country's largest service sector exports (Institute of International Education, 2012). Clearly, US universities and colleges are interested in attracting international students; however, how can educational institutions help make these students' learning experiences more successful? How welcoming is the learning environment for this group of learners? What happens when an international student has little or no face-to-face interaction with members of learning communities, that is, when she/ he is engaged in online learning?

While US universities and colleges are happy to accept foreign students and scholars, these new members of a learning community are expected to conform to the norms of the American academy (Albach, 2004; Marginson \& Wende, 2007). The "sink or swim" policy seems not to have changed much with the rapid growth of online learning and its movement towards transnationalism, which have significantly increased the possibilities of cross-cultural interactions. The recent introduction of massive open online courses (MOOCs), which has attracted thousands of learners around the globe, has not yet yielded evidence-based research that would help educators better serve global learners (Beattie-Moss, 2013). MOOCs, however, have revealed the need to move towards instructional models oriented to peer-to-peer learning and peer-assessment (see, for example, Piech et al., 2013).

Even though research studies (Palloff \& Pratt, 1999; Pelz, 2004), particularly those employing a sociocultural paradigm, have not neglected the topic of peer-to-peer learning, they have paid little attention to the role peers play in the learning experiences of international students taking fully online courses. Previous research (Shattuck, 2005; Thomson \& Ku, 2005; Zhang \& Kenny, 2010), however, indicates that international students may indeed experience significant difficulties when taking online courses designed for domestic consumption. These difficulties are linked to a number of factors where educational background and language-related aspects are most visible and discussed.

The mismatch between previous educational experience in the student's home culture and the requirements of the host institution embedded into the host culture may result 
in international students' confusion, frustration, unmet course expectations, and disappointment with the learning process and results (Pan, Tsai, Tsai, Tao, \& Cornell, 2003; Sadykova \& Dautermann, 2009; Shattuck, 2005). The American online classroom predominantly based on constructivist tenets and Socratic methods of knowledge acquisition, which values critical thinking and problem-solving skills (Greenholtz, 2003), may not be the same learning format many international students have been exposed to in their native countries (Wang, 2007; Zhang \& Kenny, 2010). As a result international students may be unprepared to participate in discussions, group and individual projects on the level expected. For example, they may refrain from challenging and criticizing ideas (Thomson \& Ku, 2005; Biesenbach-Lucas, 2003), they may prefer to use 'powerless' language such as disclaimers, hedges, and tag questions (J une \& Park, 2003), and they may misunderstand task sharing and decision making procedures employed by their 'native' classmates (McLoughlin, 1999). International students with limited previous exposure to a host culture may find it too overwhelming, challenging, and frustrating when course topics have little relevance to their native discourse systems and when their peers and instructors use cultural references that hinder learning the course content (Shattuck, 2005; Thomson \& Ku, 2005).

To keep up with discussions, write papers, and do other class assignments, international students not only have to possess rich vocabulary, good command of grammar rules, and adequate academic writing skills, but also need to be aware of colloquialisms, set phrases, slang, culturally specific analogues, and metaphors (Bentley, Tinney, \& Chia, 2005; Ciano, 2003; McBrien, 2005; Shattuck, 2005; Tan, Nabb, Aagard, \& Kim, 2010; Zhang \& Kenny, 2010). In the virtual learning environment, language issues are further complicated by the lack of visual cues and immediate feedback. The online classroom shows "great potential for misreading communicative strategies such as turn taking, criticizing, apologizing, recasting, switching registers, etc." (Sadykova \& Dautermann, 2009 , p. 98). Inadequate language skills and lack of understanding of communication rules may lead to developing a fear of speaking (Shattuck, 2005).

In such a context, both 'native' and international peers, may end up playing the role of the more significant knowledgeable others (Vygotsky, 1978), by lending a helping hand and assisting their less experienced peers in navigating and succeeding in unfamiliar waters of the host educational institution. This study describes some of the roles that peers may play in the learning experiences of international students who are enrolled in fully online courses offered through a US university.

\section{Method}

The data for this paper comes from a larger two-year research study that examined the interplay of host and native cultures in an online learning environment and researched its effect on international students' learning experiences. The research revealed that 
international students might experience conflicts of identity which do not just complicate their learning, but could also "stimulate individual growth and result in cognitive shifts such as the shift in epistemological beliefs" (Sadykova, 2013, p. 35). Peers were found to play one of the most important roles in how an international student might react to the conflicts of identity that emerge when host and native cultures meet in a multicultural online classroom. This study will investigate the peerto-peer online interactions and examine the significance of online peers, specifically US classmates, in the learning experiences of their non-US counterparts.

The study was conducted within the sociocultural paradigm, particularly within the theoretical constructs put forward by Russian psychologist Lev Vygotsky and American scholars Ron Scollon and Suzanne Wang Scollon. The sociocultural theoretical framework emphasizes the importance of social and contextual factors and underlines the significance of culture in communication. This framework enabled the research to focus on the learning experiences of a specific student and to study the effect of the social environment and culture on interactions between peers in a classroom. Vygotsky's theory of learning as an essentially social process and his focus on the mediating role of a more knowledgeable 'other' in the development of a learner and her/ his subsequent internalization of culture-specific psychological tools (i.e., signs, texts, formulae, or graphic organizers) (Vygotsky, 1978) guided all the stages of the study - from the research design to data interpretation. Informed by Scollon and Scollon's (2001) view of communication as interpersonal rather than intercultural, but affected by an idealogical position of culture, this study was able to avoid stereotyping and oversimplification in addition to investigating closely the peer-to-peer interactions in an online learning environment.

The research consisted of a two-stage, mixed methods study (see Figure 1). First, a cross-sectional survey was administered to international students who had taken at least one online course at a large research university situated in the northeastern region of the US. A questionnaire consisting of 36 items served as a survey instrument. The survey included mostly closed-ended questions related to participants' demographic information, reasons to take an online course, and likes/ dislikes of course activities. The survey also included 25 Likert-scale statements that participants needed to agree or disagree with, a space for optional comments, and finally a space for writing a pseudonym (a nickname) for those participants who were willing to be further interviewed. 


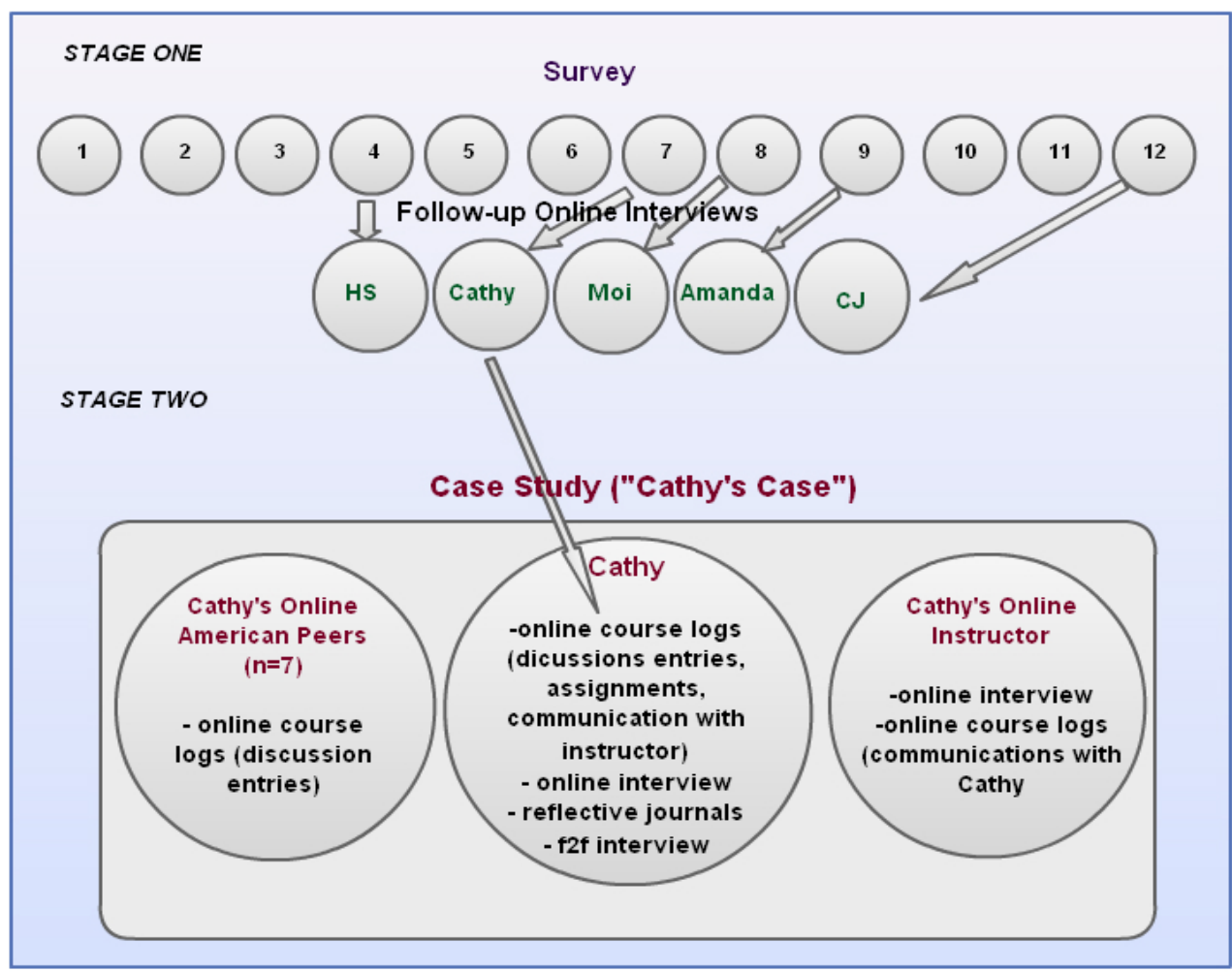

Figure 1. Research design.

To recruit the study participants, an invitation letter was sent through a university listserve distributed among all international students of the university where the study was conducted. A total of 12 international students $(\mathrm{N}=12)$ from various graduate online courses volunteered to complete the anonymous questionnaire ( $12 \%$ response rate): five students from China, two students from Turkey, two students from Nepal, and one student from each of the following countries - India, Nigeria, and South Korea. Five of these international students indicated that they would like to be further interviewed. All five volunteers satisfied the following sampling criteria:

- their native country was other than the US;

- they indicated their native language was other than English;

- they took at least one online course in the university where the study was conducted;

- they were able to communicate in English as was evident from the online survey they had completed. 
Upon signing informed consent forms, these five international students, who selected for themselves nicknames, Cathy, Amanda, CJ , HS, and Moi, participated in two rounds of online interviews.

The survey and follow-up interviews showed that Cathy, one of the study participants, might become a very good key informant for a case study. Cathy belonged to the largest group of international students who come to study in the US and thus she could represent a typical case. On the other hand her survey and follow-up interviews showed that at the moment of research she took her first US online course while residing in her native city of Shanghai, China, and she was planning to come to the US to study on campus. This made her an excellent candidate for purposeful intensity sampling as she "manifest[ed] the phenomenon intensely, but not extremely" (Patton, 1990, p. 182). Moreover, Cathy's online instructor happened to be a research advisor of the author of this study, which made the collection of data more feasible and convenient. Therefore, Cathy was contacted again and invited for additional online and face-to-face interviews after the course was over, to which she agreed. Her online instructor volunteered to help with collecting other data for Cathy's case study. At the end of the online course, Cathy's American classmates were asked to permit the instructor to forward the researcher their online posts. Seven of Cathy's colleagues agreed to do so. Cathy's online instructor also agreed to be interviewed. In addition, Cathy was asked to keep a reflective journal when she came to the U.S. to study on campus. This enabled the collection of rich data for Cathy's case that formed the core of the current study.

Qualitative data derived from online and face-to-face interviews, reflective journals, and online course logs (with an exception of logs belonging to Cathy's American peers) underwent content analysis, that is, "the process of identifying, coding, and categorizing the primary patterns in the data" (Patton, 1990, p. 381).

Besides raw numbers from the survey, quantitative methods of corpus-based linguistics were used to analyze and compare discussion posts of Cathy and her US peers. This analysis enabled close examination of the students' linguistic choices, the process that proved instrumental for studying interactions within an online course and for examining the linguistic manifestation of students' cultural affiliations.

Table 1 summarizes data sources, participants and their demographic data, as well as a method of data analysis for each of two research stages. 
Table 1

Data Sources, Participants, Demographic Data, and Methods of Data Analysis

\begin{tabular}{|c|c|c|c|c|}
\hline $\begin{array}{l}\text { Research } \\
\text { stage }\end{array}$ & Data source & Participants & Demographic data & $\begin{array}{l}\text { Method of data } \\
\text { analysis }\end{array}$ \\
\hline \multirow[t]{2}{*}{ Stage 1} & Survey & $\begin{array}{l}12 \text { international } \\
\text { students who } \\
\text { took a fully } \\
\text { online course(s) } \\
\text { in a US } \\
\text { university }\end{array}$ & $\begin{array}{l}\text { China - } 5 \text { participants } \\
\text { Turkey - } 2 \\
\text { participants } \\
\text { Nepal - } 2 \text { participants } \\
\text { India, Nigeria, and } \\
\text { South Korea - } 1 \\
\text { participants from each } \\
\text { country }\end{array}$ & $\begin{array}{l}\text { Quantitative } \\
\text { (raw numbers } \\
\text { for all close- } \\
\text { ended } \\
\text { questions) } \\
\text { Qualitative } \\
\text { (coding for } \\
\text { themes of one } \\
\text { open ended } \\
\text { question item) }\end{array}$ \\
\hline & $\begin{array}{l}\text { Follow-up } \\
\text { online } \\
\text { interviews }\end{array}$ & $\begin{array}{l}5 \text { international } \\
\text { students who } \\
\text { completed the } \\
\text { survey }\end{array}$ & $\begin{array}{l}\text { Amanda - China, } \\
\text { female } \\
\text { Cathy - China, female } \\
\text { CJ - South Korea, } \\
\text { female } \\
\text { HS - China, male } \\
\text { Moi - Nigeria, male }\end{array}$ & $\begin{array}{l}\text { Qualitative } \\
\text { (coding for } \\
\text { themes) }\end{array}$ \\
\hline \multirow[t]{5}{*}{ Stage 2} & $\begin{array}{l}\text { Documents } \\
\text { (online } \\
\text { course logs) }\end{array}$ & $\begin{array}{l}\text { a) } 7 \text { Cathy's } \\
\text { online American } \\
\text { peers } \\
\text { b) Cathy } \\
\text { c) Cathy's } \\
\text { instructor }\end{array}$ & $\begin{array}{l}\text { a) U.S.A. } \\
\text { b) China } \\
\text { c) U.S.A. }\end{array}$ & $\begin{array}{l}\text { Quantitative } \\
\text { (word } \\
\text { frequencies) } \\
\text { Qualitative } \\
\text { (coding for } \\
\text { themes) }\end{array}$ \\
\hline & $\begin{array}{l}\text { Online } \\
\text { interview } \\
\text { with Cathy's } \\
\text { online } \\
\text { instructor }\end{array}$ & $\begin{array}{l}\text { Cathy's online } \\
\text { instructor }\end{array}$ & U.S.A. female & $\begin{array}{l}\text { Qualitative } \\
\text { (coding for } \\
\text { themes) }\end{array}$ \\
\hline & $\begin{array}{l}\text { Online } \\
\text { interview } \\
\text { with Cathy }\end{array}$ & Cathy & China, female & $\begin{array}{l}\text { Qualitative } \\
\text { (coding for } \\
\text { themes) }\end{array}$ \\
\hline & $\begin{array}{l}\text { Face-to-face } \\
\text { interview } \\
\text { with Cathy }\end{array}$ & Cathy & China, female & $\begin{array}{l}\text { Qualitative } \\
\text { (coding for } \\
\text { themes) }\end{array}$ \\
\hline & $\begin{array}{l}\text { Cathy's } \\
\text { reflective } \\
\text { journals }\end{array}$ & Cathy & China, female & $\begin{array}{l}\text { Qualitative } \\
\text { (coding for } \\
\text { themes) }\end{array}$ \\
\hline
\end{tabular}


This study involved both qualitative and quantitative methods, but considering the research questions and the selected theoretical framework, qualitative methods took precedence over quantitative. When properly designed, qualitative inquiry enables the respondents to reveal "depth of emotion, the way they have organized their world, their thoughts about what is happening, their experiences, and their basic perceptions" (Patton, 2001, p. 21). The qualitative approach was selected as the leading method of data collection and analysis in this research because the aim of this study was to examine learning experiences of online international students, to learn what they think about online learning environments and about learning within a US academic discourse and with US peers and instructors. Moreover, due to the nature of the research questions, the study was planned as a naturalistic inquiry (i.e., the study of naturally occurring real-world situations) and with a holistic perspective that focuses "on complex interdependencies not meaningfully reduced to a few discrete variables and linear, cause-effect relationships" (Patton, 1990, p. 40), and therefore the domination of qualitative methods was inevitable.

The employment of a mixed research paradigm that involved both qualitative and quantitative methods of data collection and analysis enabled collecting rich data and served the purposes of data triangulation and validation of study findings. The mixed methods approach allows the researcher to neutralize biases inherent in a single approach (Creswell, 2003). Moreover such "methodological pluralism" is said to frequently result "in superior research (compared to monomethod research)" (Burke Johnson \& Onwuegbuzie, 2004, p. 14), is currently supported by experts in research design (see, for example, Creswell, 2008 or Tashakkori \& Teddlie, 2003), and has recently been actively employed by many researchers (Bryman, 2006).

All procedures involved in the participants' recruitment and selection (including necessary modifications to these procedures) were approved by the Institutional Review Board (IRB) of the university where the study was conducted. All study participants, excluding anonymous survey participants, granted their informed consents. All five students who participated in the survey and online interviews received a gift card of $\$ 50$. Cathy also received an additional $\$ 50$ after all data for her case were collected. The researcher did not meet or know personally before the study any of the international and American students who participated in the study.

As the case study was the most significant source of data, the research findings have limited generalizability to larger populations. A participant selection bias might have also served as a limiting factor. The research involved a self-selected group of participants who provided data in the English language mostly via the Internet (except for a face-to-face interview with Cathy). This might have attracted those students who had higher language proficiency levels and who were also more proficient in technologies than an average international student. The research was conducted by a single researcher and investigator triangulation was not used, which possibly limited analytic validity of the study. 


\section{Findings}

In this study three major themes cut through the research data related to peer-to-peer learning: a) the value of learning from/ with peers, b) personal relationships as a key to learning, and c) peers as a cultural entity.

\section{The Value of Learning From/ With Peers}

\section{Survey and follow-ups.}

The value of learning from and with peers was a recurrent theme that emerged during the entire process of data analysis beginning with the survey data. To gain an insight into students' preferences for course activities and to learn how group activities ranked in the other course requirements, three survey questions asked respondents to indicate their most liked, most disliked, and most difficult activities (Questions 7, 8, and 9 respectively). The results of the survey demonstrated that whole group discussions were favorite activities for 6 out of 13 respondents (Figure 2), but it was also the most disliked activity for three international students who completed the survey (Figure 3). Small group discussions were preferred at the same rate as reading lectures and individual projects (Figure 2). Four respondents stated they enjoyed discussing topics in small groups, while none of the respondents named this activity as most disliked or most difficult. Team projects, on the other hand, were selected as the most liked and as the most difficult activity only once by two different respondents (see Figure 2 and Figure 4 respectively).

Activities that do not generally involve interaction with peers also had their fair share in students' answers. Individual projects and reading lectures were among favorites for four respondents, while three respondents liked reading course texts (see Figure 2). Individual projects were also selected as the most disliked activity by two respondents and as the most difficult activity by four respondents (Figure 3 and Figure 4 respectively). 


\section{Q7. What online course activities did you like most?}

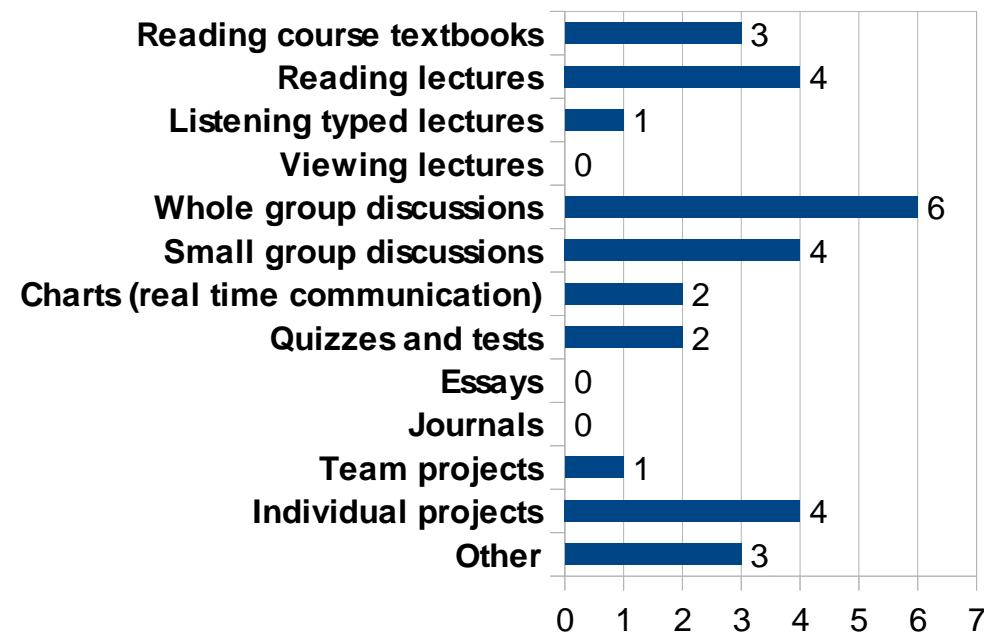

number of respondents

\section{Q8. What online course activities did you dislike most?}

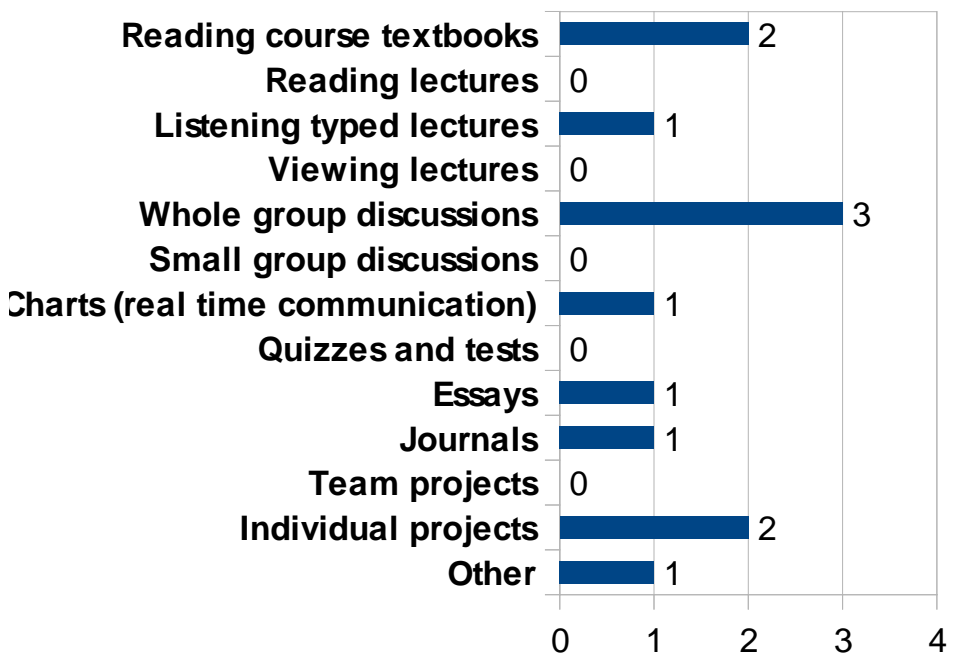




\section{Q9. What online course activities did you find most difficult?}

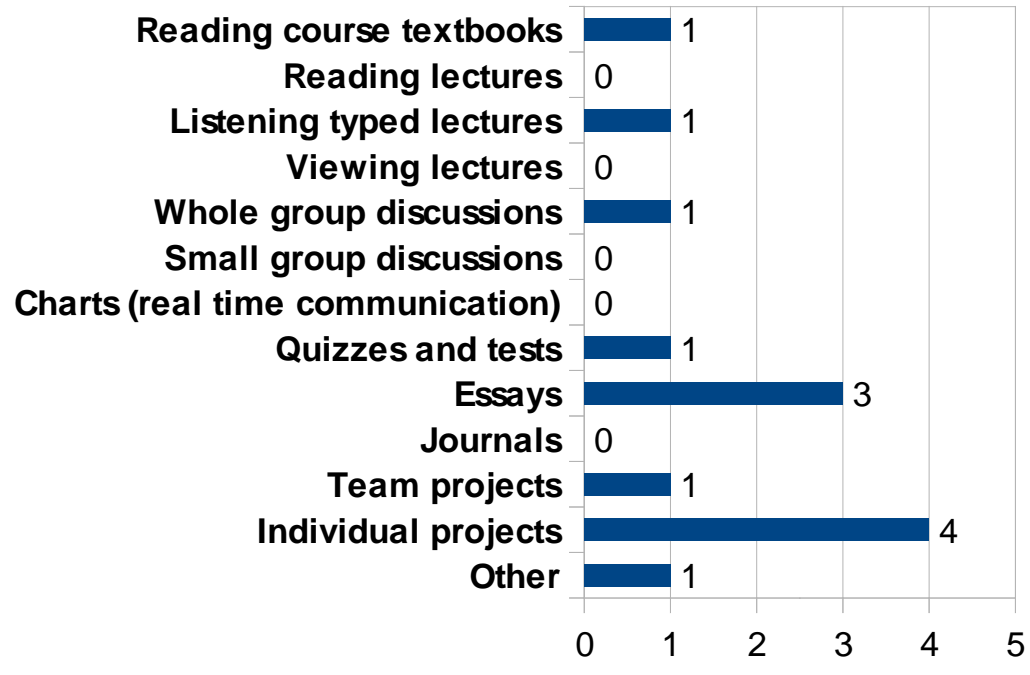

number of respondents 
She wrote, "two heads are better than one" (CJ , follow-up online interview). Amanda corroborated CJ 's reason by stating, "it is hard to manage and think about a whole idea by oneself" (Amanda, follow-up online interview). Clearly, the lack of someone to turn to in order to discuss the project, share ideas, learn how-to's, and get a push to avoid procrastination were regarded as factors that made learning more difficult for these international students.

Overall the results of the survey and interviews with the follow-up interviewees reveal that international students may value group activities for the ability to connect with their peers, learn from their experiences, and take advantage of their knowledge of the field of study. Group activities enable international students to compensate for the lack of psychological tools (Vygotsky, 1978), which are culture specific and therefore are not readily available to students who are new to a host culture. This is further confirmed by data derived from Cathy's case study.

\section{Cathy's case.}

Cathy's responses in the survey, interviews, and her course transcripts show her strong preference for learning with and from peers. Her need and desire to learn from her classmates are evident in a number of discussion posts she addressed to her classmates throughout the course including this one: "I am very pleased to know you experienced classmates and hope that I can learn from you"2 (Cathy, online course logs).

The following post, however, illustrates Cathy's difficulties related to using communication strategies valued in her newly adopted learning community:

I am partially satisfied with the quality of my posts on relevance and truism, but very disappointed with my interaction with my peers in class and my skills for moving the discussion forward. (Cathy, retrospective analysis, online course assignment)

Holding a strong belief in the value of learning from and with peers, Cathy understands that she needs to develop skills required to perform well in American-centric online discussions. Apparently, she has found that small group activities are more appropriate for her learning style and her learning needs. In the survey, she selected small group discussions, chats, and team projects as her favorite activities, and the only individual activity that she favored was reading textbooks. However, Cathy chose whole group discussions as her least favorite activity because she felt they tend to be "more general and superficial" than small group discussions.

When justifying her positive attitude to small group discussions, Cathy talked about their role in promoting "deep discussions" and encouraging interpersonal 
communication. Team projects in her assessment were described as activities where "each team member can made best use of their personal strengths to co-labor under one task. . ." (Cathy, follow-up interview). Clearly Cathy placed high value on cooperation and collaboration and saw the benefits of uniting team efforts for producing the best possible learning outcome.

Cathy further reveals why some international students may find individual projects difficult and may prefer group projects:

Since it is my first course taken outside China, and it is in my second language, I am not very familiar with something like the right format of an easy ${ }^{3}$ and the criteria of good individual projects. By doing team projects, I learn from other team member and I grow out of it as well. (Cathy, follow-up interview)

Cathy's words here remind us that international students' learning experiences may be negatively affected by their lack of familiarity with the format of activities used in the US academic discourse. As outlined above, follow-up interview participants also pointed to this issue. Similar findings are reported in a number of studies that have explored learning experiences of international students studying on campus and online (Arkoudis \& Tran, 2010; Krampetz, 2005; Thomson \& Ku, 2005). In Vygotsky's terms this could be explained by the mismatch of psychological tools that exists between educational systems in the US and in other countries. Moreover, Cathy's previous educational experience did not provide her with strategies for applying those psychological tools in ways that are generally expected in the US academic discourse. For example, in her retrospective analysis of a team project, Cathy described her newly acquired skills working on a team project in a small group and pointed out the benefits of such an experience for her as a student: “... I learn a lot through this process regarding the media use and the team work" (Cathy, retrospective analysis, online course assignment).

Collaborative work, where group members share responsibilities as they develop a group product, seemed to be a new idea for Cathy. The skills for working collaboratively, however, are essential for successful group work in the US education setting. In Asian cultures such as Taiwanese, working cooperatively on a learning product, that is, not dividing work but rather doing it together, is more common as pointed out by Ingram and Hathorn (2004). Data indicated that Cathy first failed to do her part of the work, but her group mates were able to provide adequate scaffolding and demonstrated how to work in groups the 'American way'. Cathy's later posts demonstrated that she grasped the idea very well inasmuch as she readily informed her group mates of her progress, encouraged them to do their part, and thanked them for the work done. 
In the online interview Cathy's online instructor also noticed the importance of peers for Cathy's success in the course:

The notion of working in groups for those who are new to online learning tends to be unsettling at first, especially for those unaccustomed to working in groups as part of instruction. Cathy, from China, fell behind early on as she was unclear about how the course worked, but quickly caught up with the help of her group members. (Cathy's online instructor, online interview)

Cathy's instructor's observations speak of the valuable help that Cathy was able to receive from her classmates. They also suggest that anyone with little experience in working with online team activities within a constructivist-based classroom needs to be provided with assistance and extra scaffolding to ensure that she/he understands the rules of working in an online team and collaborating on a group product. Such an activity might be unfamiliar to some international students, as indicated in Cathy's own posts, in the post of her instructor, and in related literature (Sadykova \& Dautermann, 2009). Without the extra help of peers and/ or the instructor, a student may fall behind and eventually drop out of the course. In Cathy's case such help was especially important at the beginning of the course. Cathy reported being overwhelmed by the amount of work she did not expect to have. She also blamed her shy nature stating that it prevented her from asking for help from her peers from the very beginning. The statement below illustrates this clearly.

I think it was mainly because I was kind of shocked by the amount of assignment required by instructor... I had no idea about what it was like to do a good project. And it was a little bit difficult for me to finish all reading in time, given they are heavy in amount and they are in English rather than Chinese. Besides, I was sometimes shy to turn to my classmates for help, but I successfully adapted to learn to resort to others in the end. (Cathy, follow-up interview)

Clearly, it was Cathy's lack of previous experience working in US graduate courses that caused her initial disappointing performance. She did not expect to have such heavy reading requirements. Moreover, her previous educational experience (all in China and all face-to-face) did not provide her with adequate psychological tools for learning. It was Cathy's group mates who basically played the role generally left to instructors. They ensured that Cathy stayed afloat, caught up, and eventually succeeded in her educational journey through foreign bumpy roads with minimal road signs. Using Cathy's online instructor's words, American classmates took international students "under their wings and mentored them along" (Cathy's online instructor, online 
interview). However, it was the instructor who set up team projects that ensured that Cathy had those mentors to help her.

Summing up, data suggest that international students taking online courses in the US may find themselves in a class built on student-centered practices that encourage peerto-peer interactions. International students may like taking advantage of class discussions, team projects, chats, and other collaborative activities. They appreciate such an opportunity and they value their classmates' readiness to share their knowledge and experience. Peers may successfully assume the role of a more knowledgeable other by contributing not only to the course content but to what is often more valuable for international students, that is, to the peers' understanding of the course activities, to project formats, academic writing and presentation conventions, and to the selfconfidence of those who need to be reassured of their abilities.

While the study's findings show some of the benefits of a constructivist classroom for those international students who took part in this study, they cannot be widely generalized. It is worth pointing out that previous studies reported that international students may feel uncomfortable participating in discussions and team projects with American peers due to inadequate language skills (Ciano, 2003; Zhang \& Kenny, 2010), uncertain or culturally inappropriate rules of communication (Shattuck, 2005; Pan, Tsai, Tsai, Tao, \& Cornell, 2003), somewhat aggressive and critical forms of discussion (Thomson $\& \mathrm{Ku}, 2005)$, or unfamiliar, unclear, or culturally unacceptable rules of working on a team (Chen, Hsu, \& Caropreso, 2006; Shattuck, 2005). In some cases this may result in marginalization and isolation of international students (Shattuck, 2005). However, as we see in Cathy's case, this discomfort, which at the beginning could have hindered student's participation, may then be overcome and lead to a very fulfilling and rewarding learning experience. Peer assistance is very valuable in this process.

\section{Personal Relationship as a Key to Learning: Cathy's Case}

Cathy's discussion posts, messages to her group mates, reflective journals, and interview transcripts are full of sentences that emphasize the importance of a social factor in learning. She repeatedly stresses the necessity to establish interpersonal relationships with her classmates as can be seen in the statement that follows: "I need to talk more with my instructor and my classmates, building up interpersonal relationship to facilitate active communication" (Cathy, reflective journal).

The very fact that small-group activities are her favorite illustrates Cathy's desire to establish a closer relationship with others with whom she shares a learning space. Her classmates have become her family, where " $\mathrm{I}$ " is a part of "we" and where a success of one member is seen as a success of the whole group. This is reflected in her statement as follows: "...your words are so inspiring and encouraging. I am so proud of being a member of this family" (Cathy, online course logs). 
Clearly, Cathy demonstrates her longing for social presence. Social presence, along with teaching presence and cognitive presence, constitute the elements of the community of inquiry (CoI) framework (Garrison, Anderson, \&Archer, 2000; Garrison, 2011). The CoI framework has been widely used as a leading theoretical model to guide studies in online learning in higher education (Shea et al., 2010). Social presence is defined as "the ability of participant identify with a group, communicate purposefully in a trusting environment, and develop personal and affective relationships progressively by way of projecting their individual personalities" (Garrison, 2011, p. 23). In an online learning environment, social presence is "the degree to which a person is perceived as "real" in mediated communication" (Ganawardena \&Zittle, 1997, p. 8); it is "about relationships, connecting with others despite physical separation" (Irwin \& Berge, 2006). In the absence of face-to-face contact, such a relationship is not easy to develop and maintain. However, a classroom built on the constructivist ideas that promote a high level of interaction and engagement among peers does create conditions needed for such a relationship to develop (Lock, 2002).

Cathy's and her online classmates' engagement in the learning process and interest in each others' affairs is evident in the high frequency of pronouns they used referring to themselves and others when exchanging messages in the discussion forum. Table 2 demonstrates the results of comparative quantitative analysis of Cathy's and her American peers' usage of pronouns in the discussion forums and course assignments. The analysis was carried out with the assistance of the Simple Concordance Program freely available at http://www.textworld.com/. As seen in the table, personal pronouns (I, my, you, they, we, etc.), as well as possessive pronouns and determiners (me, mine, our, yours, etc.), were frequently utilized by Cathy and her American peers. Selfdisclosure and open expression of emotions, which generally involve a high frequency of personal pronouns, are evidence of social presence (Garrison, 2011), just as a high frequency of possessive pronouns are believed to be indicative of community (Hughes, Ventura, \& Dando, 2007). Thus, the frequent usage of pronouns by Cathy and her classmates indicates that social presence was indeed established in the course under analysis.

Table 2

Frequency of Pronouns in Cathy's and her American Peers' Online Discussion Posts

\begin{tabular}{lll}
\hline Pronouns & Cathy & American students \\
& $\mathrm{N}=16660$, Nfreq $=2489$ & $\mathrm{~N}=70866$, Nfreq $=5424$ \\
\hline $\mathrm{I} / \mathrm{my} / \mathrm{me} / \mathrm{mine}$ & $2.27(378)$ & $2.92(2075)$ \\
We/ us/ our/ ours & $1.55(259)$ & $1.25(887)$ \\
They/ their/ them/themselves & $1.0(167)$ & $1.49(1055)$
\end{tabular}

Note 1. Frequency is given in percent. Raw numbers are provided in brackets. Note 2. N is word count, i.e., overall number of words in corpus. Nfreq is word vocabulary, i.e., number of different words in the corpus. 
Cathy's willingness and necessity to feel personally connected to her online peers is also well illustrated in a particularly close relationship, which may be classified as a friendship, with J ennie, one of the team members with whom Cathy worked throughout the whole online course and also did a pair project. Course transcripts and interviews revealed that both J ennie and Cathy interacted with each other on a regular basis and utilized not only discussion spaces set up in the online learning platform, but also a synchronous form of communication, Skype, which enabled them to carry out real-time conversations.

Thus, establishing a personal friendly relationship with classmates may become a matter of necessity for international students like Cathy. This aligns with research findings that demonstrate that "social interaction with people from the United States seemed to have a positive effect on international students by linking them to resources, increasing satisfaction levels, decreasing alienation, and enhancing the adaptation process" (Kim \& Sedlasek, 1995, p. 6). However, being electronically mediated, online socialization is more complicated than face-to-face socialization (Garrison, 2011; Irwin $\&$ Berge, 2006), which might be particularly true for some international students who seek to build friendship with peers and learn their culture (Thomson $\& \mathrm{Ku}, 2005$ ).

Still, Cathy's data, and specifically her close interaction with one of her online classmates, supports previous findings that showed that an online classroom built on collaborative learning activities enables the development of social presence, that is, it does provide space for developing a personal relationship (Richardson \& Swan, 2003; Rovai, 2002). On the other hand, it is important to keep in mind that because the development of a social presence in an online environment requires more effort, international students like Cathy may avoid online courses or minimize the number of courses they take at a time if given a choice (Tan, Nabb, Aagard, \& Kim, 2010; Thomson $\& \mathrm{Ku}, 2005)$. This might be more so for students from collectivistic high-context cultures than for their peers from individualistic low-context cultures: the need for "togetherness" is more prominent for those whose "I" is more often blended with "we" as we see it was for Cathy. These findings support a study conducted by Morse (2003) that reported that online students from high-context cultures (China, Singapore, Sri Lanka, and Thailand) lamented about not being able to form social relationships with counterparts, which was not the case with students from low-context cultures (the US, the UK, Australia, and New Zealand).

\section{Peers as a Cultural Entity}

For international students like Cathy establishing personal relationships may mean more than the availability of peers to help with academic matters. Data show that Cathy's high interest in making American friends was in many ways based on her desire to learn the culture of her peers. Her individual curiosity, as well as her professional interests (majoring in TESOL she would have been taught the importance of learning about the target culture) might be the two major sources of her willingness to learn the 
culture. For Cathy the very possibility to learn the host culture was the major point of attraction for studying on campus. She states:

Being an international student, the biggest motivation for me is that you get into the culture, be assimilated into the culture. So when this aspect is concern, I'd rather say that you should be exposed to the culture by being on campus, being involved in f2f classroom. (Cathy, face-toface interview)

In her interview she also suggested that a face-to-face learning context, unlike an online classroom, tends to stimulate and provoke conversations about so-called "low" culture, that is, everyday culture associated with common people's lives - their hobbies, food, and family. Data, however, demonstrate that Cathy used the online format often for learning cultural phenomena associated with the American educational system. The online course she took provided a comfortable platform for discussing cultural differences in the system of education: Course activities required students to make these cultural differences visible. Therefore Cathy felt it was appropriate to talk about her native culture, as well as directly ask her peers to share their cultural experiences with her. For example, after describing teaching and learning styles in China, she hoped to get similar knowledge from her peers when writing, "It would be great if any of you can explain a little and make some comparison re what I have mentioned above" (Cathy, online course logs).

Cathy's use of the online environment to discuss both her own and the host cultures became even more visible after online course transcripts underwent quantitative analysis with the help of the Concordance software. Table 3 shows the results of frequency counts for words China/ Chinese, U.S./ US/ USA, and America/American.

Table 3

Results of Frequency Counts for Words China/ Chinese, U.S./US/ USA, and America/ American

Word frequency count for culturally associated Cathy American Students words

\begin{tabular}{lll}
\hline China, Chinese & $.5(84)$ & $.04(27)$ \\
American, America & $.12(20)$ & $.04(28)$ \\
TOTAL & $.8(134)$ & $.1(76)$ \\
\hline
\end{tabular}

Note. Frequency is given in percent. Raw numbers in brackets. 
The table demonstrates that both Cathy and her American peers talked about their cultures quite often: Cathy used these words 134 times (.8\%) and her peers 76 times (.1\%). However it was Cathy who took an initiative in these discussions and provoked her peers for discussions. The total numbers also show that Cathy was eight times more inclined to discuss the two cultures than her peers (.8\% vs. .1\%). Clearly, this demonstrates how important the question of culture is for Cathy and how much space her native Chinese culture takes up in her world view. Fortunately for her the course topics included the discussion of culture and Cathy took every opportunity to talk about her own culture, make inquiries about the US culture, and compare the two. Apparently, questions of culture were of less significance for Cathy's American peers, which arguably may be attributed to the high individualism of American mainstream culture.

Thus the study shows that for international students peer-to-peer learning may encompass learning each others' cultures. Such a culture exchange may be of no less importance for some international students than acquiring content knowledge and studying US academic writing, presentation conventions, and other tools of learning in the US. Moreover, data demonstrate that Cathy's online course provided ample opportunities for talking about cultural differences in the educational systems of two countries - US and China. Thus, while the online learning environment is currently dominated by Western cultures (Smith \& Ayers, 2006), and might be perceived as much less suitable for promoting cultural understanding as compared to on-campus learning (Tan, Nabb, Aagard, \& Kim, 2010), it is not inherently insensitive to the cultures of its inhabitants. Indeed, online courses may incorporate meaningful and relevant discussions that promote cultural awareness.

\section{Conclusion and Implications}

The study demonstrated that international students, who come from diverse cultural and educational backgrounds, may need a close relationship with peers they meet in the US online courses. This need is grounded in the inadequate command of psychological tools that an international student is required to use when functioning in the US academic discourse. The need to establish close ties with American peers could also be explained by students' high interest in learning the host culture in its broad sense. Thus, peers become invaluable mediators of knowledge for international students who seek peer assistance to compensate for the lack of culture-specific knowledge and skills and to satisfy their interest in the host culture. In the online context, students should receive peer assistance in collaborative activities set up by their instructors. While the survey participants did not show overwhelming approval of all collaborative activities, followup interviews with selected survey participants and in-depth analysis of Cathy's case data demonstrated important advantages of constructivist activities where American students are able to perform as more knowledgeable others and take international students "under their wings and [mentor] them along" (Cathy's online instructor, online 
interview). An important aspect of this finding is that it is the instructor's responsibility to establish beforehand peer support groups when designing collaborative course activities, and provision of this will help determine how international students are included in such a course.

Cathy's case data also demonstrated the significance of social relationships that students, especially those who come from collectivistic high-context cultures, may seek in any format of learning - online or traditional. Developing personal relationships with peers was reported to be highly desirable for ensuring peers' assistance and for satisfying students' interest in the host culture.

These findings bear several important implications for research and practice. First of all the current research revealed that an in-depth study of international students' learning experiences in the US online courses designed for in-home consumption may show that a highly interactive constructivist learner-centered classroom might not be "a lonely place for an international online learner whose cultural experiences are different than the dominant educational cultures" as described in Shattuck (2005, p. 175). This speaks to the need for further research that would include both large-scale surveys and indepth case studies that would examine how exactly international students feel in online courses that place high value on communication. Why these students may actually prefer to be required to interact with their online peers is also worthwhile investigating. Moreover, the fact that studies of international students' learning experiences in online US courses may yield contradictory results highlights the value of the sociocultural framework that emphasizes contextual and individual factors in the study of cultural influence on learning experiences.

Practical implications of this research call for the design of online courses that enable learners to interact with each other in order to exchange knowledge related to their host cultures and to compensate for the lack of skills needed to successfully complete course assignments. This means that online courses that involve international students should strive to maximize social presence. As this study and other studies have shown, many international students would like to develop personal relationships with American peers and are highly interested in learning 'popular' American culture. To satisfy international (and some domestic) students' need for socializing and learning culture, instructors could be trained to design group and pair projects, to enhance asynchronous discussions with synchronous forms of communication, as well as to assign tasks that incorporate everyday culture into the course content. While instructors can not force students to become friends, they can maximize opportunities for such a relationship to develop when students participate in collaborative activities.

The question of culture in online classrooms gets a new turn with the recent epic hype that surrounds the development of massive open online courses (MOOCs) (BeattieMoss, 2013) and the continuing growth of transnational academic mobility (Kim, 2009; Khabutdnova \& Bayanova, 2013). Meanwhile, "bridging cultures in the context of 
computer-mediated learning environments could be as complex as the concept of culture itself" (Sadykova, 2013, p. 21). Therefore, educators should be aware of the needs that global learners bring to the classroom. This study, while based on a more traditional online learning format than MOOCs, pinpoints a highly important role that peers play in learning experiences of each other. Moreover, the research findings suggest that for peer-mediated knowledge acquisition to happen, course designers and facilitators must take leading roles in creating a learning environment conducive of productive and relationship-oriented peer-to-peer interactions. 


\section{References}

Albach, P.G. (2004, March-April). Higher education crosses borders: can the United States remain the top destination for foreign students? Change. Retrieved from http:// www.bc.edu/bc org/avp/soe/cihe/publications/pub_pdf/Student $\% 20$ flows.pdf.

Arkoudis, S., \&Tran, L. (2010). Writing blah, blah, blah: Lecturers' approaches and challenges in supporting international students. International J ournal of Teaching and Learning in Higher Education, 22(2), 169-178.

Beattie-Moss, M. (2013, June 18). Probing questions: Are MOOCs here to stay? PennState News. Retrieved from http://news.psu.edu/ story/279650/2013/06/18/ society-andculture/probing-question-are-moocs-here-stay

Bentley, J . P. H, Tinney, M. V., \& Chia, B. H. (2005). Intercultural Internet-based learning: Knowyour audience and what it values. Educational Technology Research and Development, 53(2), 117-127.

Biesenbach-Lucas, S. (2003). Asynchronous discussion groups in teacher training classes: Perception of native and non-native students. J ournal of Asynchronous Learning Networks, 7(3), 24-46.

Burke J ohnson, R., \& Onwuegbuzie, A. J . (2004). Mixed methods research: A research paradigm whose time has come. Educational Researcher, 33(7), 14- 26.

Bryman, A. (2006). Integrating quantitative and qualitative research: How is it done? Qualitative Research, 6(1), 97-113.

Chen, S., Hsu, C., \& Caropreso, E. J . (2006). Cross-cultural collaborative online learning: When the West meets the East. International J ournal of Technology in Teaching and Learning, 2(1), 17-35.

Ciano, L. (2003). Special considerations when teaching non-native English in an online environment. Teaching in the Community Colleges: 1996-2007 Presentations. Retrieved from http:// tcc.kcc.hawaii.edu/previous/TCC\%202003/ ciano.html.

Creswell, J. W. (2003). Research design: Qualitative, quantitative, and mixed methods approaches ( $2^{\text {nd }}$ ed.). Thousand Oaks, CA: Sage.

Creswell, J. W. (2008). Research design: Qualitative, quantitative, and mixed methods approaches ( $3^{\text {rd }}$ ed.). Thousand Oaks, CA: Sage. 
Gunawardena, G., \&Zittle, F. (1997). Social presence as a predictor of satisfaction within a computer mediated conferencing environment. American J ournal of Distance Education, 11(3), 8-26. doi: 10.1080/08923649709526970

Garrison, D. R. (2011). E-learning in the 21st century: Framework for research and practice ( $2^{\text {nd }}$ ed.). New York, NY: Routledge.

Garrison, D. R., Anderson, T., \&Archer, W. (2000). Critical inquiry in a text-based environment: Computer conferencing in higher education. The Internet and Higher Education, 2(2- 3), 87-105. doi: 10.1016/S1096-7516(00)00016-6

Greenholtz, J . (2003). Socratic teachers and Confucian learners: Examining the benefits and pitfalls of a year abroad. Language and Intercultural Communication 3(2), 122-130. doi: 10.1080/14708470308668096

Hughes, M., Ventura, S., \& Dando, M. (2007). Assessing social presence in online discussion groups: A replication study. Innovations in Education and Teaching International, 44(1), 17-29. doi: 10.1080/14703290601090366

Ingram, A. L., \& Hathorn, L. G. (2004). Methods for analyzing collaboration in online communications. In T. S. Roberts (Ed.), Online collaborativelearning: Theory and practice (pp. 215-241). Hershey, PA: Information Science Publishing.

Institute of International Education. (2012). Open Doors Report on International Educational Exchange. Retrieved from http:// www.iie.org/opendoors

Irwin, C. \& Berge, Z. (2006). Socialization in the online classroom. e-J ournal of Instructional Science and Technology, 9(1). Retrieved from http://www.ascilite.org.au/ajet/ejist/docs/vol9_no1/papers/full_papers/irwin_berge.htm

J une, J ., \& Park, J . H. (2003). Power relations within online discussion context: Based on adult international students' perspective and their participation in the learning context. Paper presented at the Annual Meeting of the Adult Education Research Conference (44th San Francisco, CA, J une 5-8, 2003). (ERIC Document Reproduction Service No. ED 480496).

Khabutdinova, M. M., \& Bayanova, L. (2013). Norms and values characteristics of students in a foreign cultural environment. Middle-EastJ ournal of Scientific Research, 16(11), 1527-1531. DOI:10.5829/idosi.mejsr.2013.16.11.12041.

Kim, S. H., \& Sedlasek, W. E. (1995). International students: Distinguishing noncognitive variables from social interaction patterns. Research report No. 895. (ERIC Document Reproduction Service No. ED 405528). 
Kim, T. (2009). Transnational academic mobility, internationalization and interculturality in higer education. Intercultural Education, 20(5), 395-405. doi:10.1080/ 14675980903371241.

Krampetz, E. M. (2005). Writing across cultures and contexts: International students in the Stanford Study of Writing (Master's thesis). Stanford University, USA.

Lock, J . V. (2002). Laying the groundwork for the development of learning communities with online courses. Quarterly Review of Distance Education, 3(4), 395-408. Retrieved from http://jan.ucc.nau.edu/ coesyl-p/principle10-article4.pdf

Marginson, S., \& van der Wende, M. (2007). Globalisation and higher education. Paris, France: OECD. Retrieved from http:/ / doc.utwente.nl/60264/ 1/ Marginson07globalisation.pdf

McBrien, K. (2005, May 5). Developing localization friendly e-learning. Learning Circuits. Retrieved from http:// www.astd.org/LC/ 2005/0505_mcbrien.htm.

McLoughlin, C. (1999). Culturally inclusive learning on the web. In K. Martin, N. Stanley \&N. Davison (Eds.), Teaching in the disciplines/ Learning in context:. The proceedings of the 8th Annual Teaching and Learning Forum (pp. 272277). Retrieved from http:/ / lsn.curtin.edu.au/ tlf/tlf1999/mcloughlin.html

Morse, K. (2003). Does one size fit all? Exploring asynchronous learning in a multicultural environment. J ournal of Asynchronous Learning Networks, 7(1). Retrieved from http:// sloanconsortium.org/jaln/v7n1/ does-one-size-fit-allexploring-asynchronous-learning-multicultural-environment

Pan, C.-C, Tsai, M.-H., Tsai, P.-Y., Tao, Y., \& Cornell, R. (2003). Technology's impact: Symbiotic or asymbiotic impact on differing cultures? Educational Media International, 40(3-4), 319-330. doi: 10.1080/ 0952398032000113239

Patton, M. Q. (2001). Qualitative research and evaluation methods (3rd ed.). Thousand Oaks: Sage.

Piech, C., Huang, J ., Chen, Z., Do, c., Ng, A., \& Koller, D. (2013). Tuned models of peer assessment in MOOCs. In S.K. D'Mello, R.A. Calvo \&A. Olney (Eds.). Proceedings of the 6th International Conference on Educational Data Mining (J uly 6-9, Memphis, TN, USA). (pp.153-160). Retrieved from https:/ / dl.dropboxusercontent.com/u/23793540/EDM\%202013\%20Proc eedings.pdf.

Richardson, J . C., \& Swan, K. (2003). Examining social presence in online courses in relation to students' perceived learning and satisfaction. J ournal of Asynchronous Learning Networks, 7(1), 68-88. Retrieved 
from http://sloanconsortium.org/jaln/v7n1/ examining-social-presence-onlinecourses-relation-students039-percieved-learning-and-satis

Rourke, L., Anderson, T. Garrison, D. R., \&Archer, W. (1999). Assessing social presence in asynchronous, text-based computer conferencing. J ournal of Distance Education, 14(2), 50-71.

Rovai, A. P. (2002). Building sense of community at a distance. International Review of Research in Open and Distance Learning, 3(1). Retrieved from http:/ / www.irrodl.org/index.php/irrodl/article/ view/ 79/ 152.

Sadykova, G. (2013). Learning in new online cultures: East meets West . In C. Meskill (Ed.), Online teaching and learning (pp. 21-38). London, UK: Bloomsbury.

Sadykova, G., \&Dautermann, J . (2009). Crossing cultures and borders in international online distance higher education. J ournal of Asynchronous Learning Networks, 13(2), 89-114. Retrieved from http:// sloanconsortium.org/jaln/v13n2/ crossing-cultures-and-bordersinternational-online-distance-higher-education

Scollon, R., \& Scollon, S. W. (2001). Intercultural communication: A discourse approach. Malden, MA: Blackwell Publishing.

Shattuck, K. (2005). Glimpses of the global Coral Gardens: Insights of international adult learners on the interactions of cultures in online distance education (Doctoral dissertation). Retrieved from PennState Electronic Theses and Dissertations database: https:// etda.libraries.psu.edu/ paper/6685/

Shea, P., Hayes, S. Vickers, J ., Gozza-Cohen, M., Uzuner, S., Mehta, R., Valchova, A., \& Rangan, P. (2010). A re-examination of the community of inquiry framework: Social network and content analysis. The Internet and Higher Education, 13, 10-21. doi: 10.1016/j.iheduc.2009.11.002

Smith, D. R., \&Ayers, D. F. (2006). Culturally responsive pedagogy and online learning: Implications for the globalized community college. Community CollegeJ ournal of Research and Practice, 30, 401-415. doi: 10.1080/10668920500442125

Tan, F., Nabb, L., Aagard, S., \& Kim, K. (2010). International ESL graduate student perceptions of online learning in the context of second language acquisition and culturally responsive facilitation. Adult Learning, 21(1-2), 9-14. doi: 10.1177/ 104515951002100102

Tashakkori, A., \& Teddlie, C. (Eds.). (2003). Handbook of mixed methods in social and behavioral research. Thousand Oaks, CA: Sage. 
Thompson, L., \& Ku, H-Y. (2005). Chinese graduate students' experiences and attitudes towards online learning. Educational Media International, 42(1), 33-47. doi: 10.1080/09523980500116878

Vygotsky, L. (1978). Mind in society: The development of higher psychological processes (M. Cole, V.J ohn-Steiner, S. Scribner, \&E. Souberman, Eds.). Cambridge, MA: Harvard University Press.

Wang, M. (2007). Designing online courses that effectively engage learners from diverse cultural backgrounds. British J ournal of Educational Technology, 38(2), 294311. doi: 10.1111/j.1467-8535.2006.00626.x

Zhang, Z., \& Kenny, R. F. (2010). Learning in an online distance education course: Experiences of three international students. International Review of Research in Open and Distance Learning, 11(1), 17-36. Retrieved from http:// www.irrodl.org/index.php/irrodl/article/ view/ 775/ 1481

\section{Athabasca University $\mathbf{Z}$}

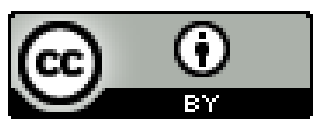

